\title{
ISLAM DAN ADAT DALAM TRADISI PERKAWINAN MASYARAKAT SUKU BUGIS: ANALISIS INTERAKSIONISME SIMBOLIK
}

\author{
Abd. Sattaril Haq \\ UIN Sunan Kalijaga \\ Yogyakarta \\ sattarilhaq@gmail.com
}

\begin{abstract}
This article is intended to examine the relationship between Islam and adat in the Bugis traditional wedding procession by using symbolic interactionism analysis. The procession of the Bugis traditional wedding tradition is divided into several parts, namely mappese-pese or mabbaja laleng which is interpreted as a process to find out whether the couple to be married has a fiance or not, this is intended as a form of caution not to propose to a woman who has been proposed. by other people. Madduta is done as a form of appreciation or love among humans. Mappettu ada is meant to reinforce the outcome of the conversation and is intended to elevate the position of women in the procession. Mappacci is meant to carry out the self-cleaning process by using several traditional instruments and using the Koran and praise to the Prophet in the form of reading barazanji as its main foundation and giving leko' is meant as a form of husband's responsibility in providing for his wife. This gives legitimacy that Islam and customs in the tradition of Bugis marriage go hand in hand or a form of acceptance of the Bugis community with Islamic values described in the traditions being carried out.
\end{abstract}

Keywords: Islam and Custom, Marriage Tradition, Buginese Tribe, Symbolic Interactionism.

\begin{abstract}
Abstrak: Artikel ini dimaksudkan untuk menelaah relasi Islam dan adat dalam prosesi adat pernikahan masyarakat Bugis dengan menggunakan analisis interaksionisme simbolik. Prosesi adat tradisi pernikahan suku Bugis dibagi menjadi beberapa bagian yaitu mappese-pese atau mabbaja laleng yang dimaknai dengan proses untuk mengetahui
\end{abstract}




\section{Pendahuluan}

apakah pasangan yang akan dinikahi tersebut telah memiliki tunangan atau belum, hal ini dimaksudkan sebagai bentuk kehati-hatian untuk tidak melamar wanita yang telah dilamar oleh orang lain. Madduta dilakukan sebagai bentuk penghargaan atau cinta kasih sesama manusia. Mappettu ada dimaksudkan untuk memperteguh hasil pembicaraan dan dimaksudkan untuk meninggikan derajat perempuan di dalam prosesi tersebut. Mappacci dimaksudkan untuk melakukan proses pembersihan diri dengan menggunakan beberapa instrument adat serta menggunakan al-Qur'an dan pujian kepada Nabi dalam bentuk pembacaan barazanji sebagai pondasi utamanya dan pemberian leko' dimaksudkan sebagai bentuk tanggung jawab suami dalam menafkahi istrinya. Hal tersebut memberikan legitimasi bahwa Islam dan adat dalam tradisi perkawinan suku Bugis berjalan beriringan atau bentuk penerimaan masyarakat Bugis dengan nilai-nilai Islam dijabarkan dalam tradisi-tradisi yang dijalankan.

Kata Kunci: Islam dan Adat, Tradisi Perkawinan, Suku Bugis, Interaksionisme Simbolik.

Indonesia memiliki banyak keragaman suku dan budaya yang tersebar dari Sabang samapai Merauke. Menurut Soerjono Soekanto budaya merupakan perbuatan masyarakat yang menggambarkan sifat yang hidup dalam masyarakat itu sendiri yang wujud pengimplementasiannya sebagai bentuk pengawasan dari masing-masing anggota masyarakatnya.1 Oleh karena itu, terdapat banyak macam budaya atau tradisi yang masih dijalankan oleh masyarakat sebagai bentuk pengawasan kepada anggota masyarakatnya dan juga sebagai bentuk perhormatan kepada nenek moyangnya, misalnya budaya atau tradisi perkawinan pada masyarakat Gesikan yaitu tradisi kawin

1 Soerjono Soekanto, Hukum Adat Indonesia, (Jakarta: CV. Rajawali, t.p), 2. 
Boyong,2 yang dimaknai sebagai warisan nenek moyang yang harus dipertahankan sebagai bentuk penghormatan terhadap leluhur.3 Tidak hanya itu, tradisi Kelakat pada masyarakat Loloan Timur4 juga merupakan salah satu kultur dalam pernikahan di Indonesia yang masih dipertahankan sampai saat ini yang wujud pelaksanaannya dengan memanggil roh para leluhur agar memberikan perlindungan pada acara pernikahan serta menjauhkan dari berbagai macam mara bahaya. 5

Tidak hanya kedua penelitian di atas, masyarakat suku Bugis Makassar juga masih memegang teguh tradisi adat dalam pernikahannya yang dibuktikan banyaknya penelitian mengenai tradisi perkawinan masyarakat suku Bugis Makassar diantaranya penelitian yang dilakukan oleh Seliana, Syaiful Arifin, Syamsul Rijal tentang tradisi mappasikarawa,6 Widyawati tentang tradisi uang Panai,7 Ardillah Halim tantang tradisi mappacci,8 dan masih banyak lain penelitian terkait tentang tradisi dalam pernikahan masyarakat suku Bugis Makassar.

Dalam tradisi pernikahan suku Bugis Makassar terdapat tradisi uang panai yang dijadikan sebagai alat ukur tinggi rendahnya status sosial seseorang mencakup keturunan ningrat atau tidak, keadaan jasmani, tingkat pendidikan, profesi dan status ekonomi perempuan. Tetapi, hal yang demikian

2 Moh. Mus'id Adnan, "Tradisi Kawin Boyong dalam Perkawinan Adat Masyarakat Gesikan (Studi Kasus di Desa Gesikan Kec. Grabangan, Kab. Tuban)", (Skripsi--Universitas Negeri Malang, 2008).

3 Ibid, 102.

4 Usriah, "Tradisi Kelakat dalam Perkawinan Masyarakat Muslim Kelurahan Loloan Timur Kabupaten Jembrana Bali," dalam Jurnal Hukum dan Syariah, Vol. 1 No. 1, 25.

5 Ibid., 32.

6 Seliana et al. "Makna Simbolik Mappasikarawa dalam pernikahan suku Bugis di Sebatik Nunukan," Jurnal Ilmu Budaya, Vol. 2 No. 3 (Juni 2018), 213. 7 Widyawati, "Makna Tradisi Uang Panai dalam Adat Pernikahan Suku Bugis di Sungai Guntung Kecamatan Kateman Kabupatan Indragiri Hilir Provinsi Riau," Jurnal JOM FISIP, Vol. 5 No. 2 (Desember 2018), 1.

8 Aridiah Halim, "Tradisi Mappacci dalam Proses Pernikahan Masyarakat Bugis Persfektif Al-'Urf (Studi di desa Sengengpalie, Kec Lappariaja, Kab Watampone, Sulawesi Selatan)," (Skrips-- Fakultas Syariah Universitas Islam Negeri Malang, 2018). 
mempunyai nilai yang terkandung di dalamnya yakni nilai sosial, nilai kepribadian, nilai pengetahuan dan nilai keagamaan.9 Selain tradisi uang panai ada pula tradisi mappacci, pemberian leko, erang-erang dan lain sebagainya.

Tradisi mappacci merupakan suatu syarat yang mesti dilakukan, baik calon pengantin laki-laki ataupun calon pengantin perempuan, tepat sehari sebelum pelaksanaan ijab kabul.10 Pemberian leko pula merupakan persyaratan khusus yang mesti dibawa oleh mempelai laki-laki ke rumah perempuan sebagai bentuk penghargaan kepada calon istri dan penghargaan terhadap adat setempat, dan dapat berakibat pada penundaan perkawinan apabila pihak mempelai laki-laki tidak membawa leko tersebut.11 Selain itu erang-erang juga merupakan tradisi yang mesti ada pada saat pengantaran pernikahan.

Pernikahan merupakan hal yang sakral dalam kehidupan masyarakat suku Bugis, maka tidak jarang sebelum sampai ke tahap ijab kabul banyak tradisi dalam pernikahan yang mesti dilalui oleh pasangan yang ingin menikah. Namun, di samping tradisi yang begitu ketat, masyarakat Bugis tidak mengenyampingkan nilai-nilai agama dalam pernikahannya, bahkan memadukan antara kuatnya adat dan ajaran Islam.12

Masyarakat Bugis Makassar mayoritas memeluk agama Islam,13 jadi tak ayal jika dalam setiap dimensi kehidupannya

9 Hajra Yansa dkk, "Uang Panai" dan Status Sosial Perempuan dalam Perspektif Budaya Siri' Pada Perkawinan Suku Bugis Makassar Sulawesi Selatan," Jurnal Pena, Vol. 3 No. 2, 534.

10 Saprinah et al, "Nilai-nilai Yang Terkandung Dalam Budaya Mappacci Pada Rangkaian Pelaksanaan Perkawinan Orang Bugis (Studi di Desa Biru Kecamatan Poleang Timur Kabupaten Bombana), " Jurnal Selami Ips, Vol. 3 No. 47 (Juni 2018), 212.

11 Abd. Hayyi, Tokoh Adat Kelurahan Toronipa, Sulawesi Tenggara, Wawancara, 02 Desember 2020.

12 Ismail Suardi Wekke, "Islam dan Adat Dalam Pernikahan Masyarakat Bugis di Papua Barat," Jurnal Thaqafiyyat, Vol. 13 No. 02 (Desember 2012), 329.

13 Keharmonisan Relasi Suku Bugis dan Suku Toraja, http://www.ugm.ac.id/id/berita/18152-keharmonisan-relasi-suku-bugisdan-toraja, diakses 28 Februari 2021. 
dibarengi dengan nuansa-nuansa keislaman.14 Pada tradisi pernikahannya juga memiliki maksud dan tujuan tersendiri yang menggabungkan unsur-unsur keislaman dan tradisi lokal yang dipertahankan hingga saat ini.

Berdasarkan uraian tentang beberapa kajian relevan di atas ternyata, penelitian tersebut lebih memfokuskan pada makna tradisi perkawinan dalam dimensi adat semata yang dibuktikan dengan tradisi adat dilakukan untuk menghargai warisan nenek moyang sehingga wujud pelaksanaannya harus dilestarikan dan juga implemantasi dari penerapan tradisi perkawinan dimaknai sebagai bentuk perlindungan dari roh para leluhur agar pernikahan dapat berjalan lancar dan terlindung dari mara bahaya. Selain itu, dalam beberapa tulisan tantang tradisi perkawinan suku Bugis Makassar, memfokuskan penelitiannya pada dimensi ditetapkan serta diharuskannya tradisi adat tersebut dilaksanakan.

berdasarkan penjelasan di atas, penelitian ini akan dikonsentrasikan pada beberapa tradisi perkawinan suku Bugis untuk melihat dimensi perkawinan suku Bugis yang dijalankan tersebut memiliki relevansi kuat antara Islam dan adat atau hanya dominasi adat yang lebih kuat dibandingkan dengan Islam. Untuk menentukan posisi tersebut, maka akan digunakan analisis interaksionisme simbolik terhadap tradisi perkawinan suku Bugis sehingga dapat ditarik kesimpulan, bahwa penelitian ini akan melihat Islam dan Adat dalam Tradisi Perkawinan Suku Bugis: Analisis Interaksionisme Simbolik.

Pada penelitian ini, penulis memfokuskan pada beberapa tradisi yang dijalankan dalam perkawinan suku Bugis seperti Tradisi mappacci, Pemberian Leko', pemberian sompa atau mahar, erang-erang, Mappese-pese atau Mabbaja Laleng, Madduta dan Mappettu Ada.

Untuk mengkaji mengenai hal tersebut, penelitian ini dilakukan di kelurahan Toronipa Kecamatan Soropia Kabupaten Konawe Sulawesi Tenggara. Jenis penelitian ini merupakan penelitian lapangan, yaitu melihat Islam dan adat dalam tradisi

14 Rustan, Tokoh Agama Kelurahan Toronipa, Sulawesi Tenggara, Wawancara, 02 Desember 2020. 
perkawinan suku Bugis di Kelurahan Toronipa. Penelitian ini bersifat deskriptif-kualitatif dengan menggunakan pendekatan sosiologi. Serta menngunakan wawancara dan observasi sebagai tehnik pengumpulan datanya yaitu mengenai tradisi pernikahan suku Bugis di Kelurahan Toronipa Kecamatan Soropia Kabupaten Konawe Sulawesi Tenggara.

\section{Teori Interaksionisme Simbolik George Herbert Mead}

Penelitian mengenai Islam dan adat dalam tradisi perkawinan masyarakat suku Bugis di Kelurahan Toronipa ini dianalisis menggunakan teori interaksionisme simbolik yang dikemukakan oleh George Herbert Mead untuk mengetahui maksud dan tujuan dilaksanakannya tradisi Perkawinan. Untuk memperjelas penggunaan teori yang akan digunakan maka, peneliti akan menjelaskan mekanisme penggunaan teori tersebut dalam penelitian ini.

Interaksionisme simbolik disandarkan pada pandangan baru tentang seseorang terhadap interaksinya dalam masyarakat. Interaksionisme simbolik merupakan ciri dari interaksi manusia, yaitu menggunakan pertukaran simbol yang mempunyai makna dari interaksi yang dilakukan.15 Dalam teori interaksionisme simbolik, dinamika sosial kemasyarakatan berdasar pada interaksi seseorang menggunakan simbol-simbol yang mewakili apa yang dimaksudkan dalam berkomunikasi sesama masyarakat, serta akibat yang dihasilkan dari simbolsimbol kepada prilaku masyarakat yang terlibat dalam interaksi sosial.16

Teori interaksionisme simbolik didasarkan pada premispremis yang penjabarannya sebagai berikut: 17

1. Individu merespon suatu simbol, mereka menanggap objek jasmaniah (benda) dan obyek sosial (prilaku) menurut bagian-bagian lingkungan mereka.

15 Dedi Mulyana, Metodologi Penelitian Kualitatif, (Bandung: Rosdakarya, 2002), 68.

16 Artur Asa Berger, Tanda-Tanda dalam Kebudayaan Kontemporer, trans. M. Dwi Mariyanto dan Sumarto, (Yogyakarta: Tiara Wacana, 2004), 14.

17 Alex Sobur, Semiotika Komunikasi, (Bandung: Rosda Karya, 2004), 199. 
2. Makna yaitu produk interaksi sosial, oleh karena itu makna tidak hanya memandang pada obyek, tetapi juga dapat terjadi dalam interaksi sosial yang terjadi dalam masyarakat.

3. Makna yang dimaksudkan seseorang itu bisa berubah dari zaman ke zaman, paralel dengan prubahan kondisi yang terjadi pada masyarakat.

George Herbert Mead mengambil tiga konsep kritis yang saling memberi pengaruh satu sama lain untuk membentuk sebuah teori interaksionisme simbolik. Konsep itu adalah : Mind, Self dan Society.18 Tiga konsep itu merupakan kata kunci yang diberikan Mead dalam teorinya. Interaksionisme simbolik secara khusus menerangkan tentang bahasa, interaksi sosial dan reflektifitas.

1. Mind (Pikiran)

Pikiran yang dimaksud Mead ialah cara kerja percakapan seseorang dengan dirinya sendiri. Pikiran timbul dan berkembang dari cara kerja sosial yang termasuk komponen integral dari proses sosial. Mead memandang pikiran secara pragmatis, yakni pikiran melibatkan cara kerja pikiran yang mengarah pada penyelesaian persoalan.19

2. Self (Diri)

Berdasarkan pandangan Mead, pribadi dua sisi yaitu diri (self) dan sisi sosial (person). Karakter pribadi bisa dipengaruhi oleh regulasi, nilai-nilai dan norma adat setempat di mana seseorang itu berada dan dipelajari lewat interaksi sosial yang terjadi dalam tradisi masyarakat tersebut. Saat masyarakat menanggapi hal yang terjadi dalam lingkungan masyarakat, saat itu dia sedang mengaplikasikan sesuatu yang disebut sikap.20

3. Society (Masyarakat)

Pada tingkat paling lazim, Mead memakai istilah masyarakat (sociey) yang berarti proses sosial yang

\footnotetext{
18 Elvinaro Ardianto, Lukianti Komala dan Siti Karlinah, Komunikasi Massa Suatu Pengantar, Revisi (Bandung: Simbiosa Rekatama Media, 2007), 136.

19 George Ritzer dan Douglas J Goodman, Teori Sosiologi Modern, (Jakarta: CV Rajawali, t.p), 67.

20 Sindung Haryanto, Spektrum Teori Sosial dari Klasik Hingga Postmodern, (Yogyakarta: AR-RUZZ MEDIA, 2012), 80.
} 
mendahului pikiran dan diri. Masyarakat mempunyai peran penting dalam menyusun pikiran dan diri.

Dalam konsepnya Mead mengemukakan pembelajaran makna dan simbol, makna menurut Mead, ada dalam intraksi sosial atau lahir darinya, bukan dari mental. Tanda-tanda memiliki maknanya sendiri. Simbol merupakan objek sosial yang digunakan untuk merepresentasekan objek sosial tersebut, yaitu kata-kata dan benda fisik. Objek sosial tersebut digunakan untuk komunikasi, kata-kata juga termasuk simbol, karena bersifat menggantikan suatu yang lain.21

Penggunaan teori ini dimaksudkan untuk melacak interaksionisme simbolik yang terjadi dalam tradisi perkawinan masyarakat suku Bugis dengan melihat interaksi yang memiliki simbol atau makna yang terkuak di dalamnya

\section{Tradisi Perkawinan Masyarakat Suku Bugis}

Dalam peraktiknya, perkawinan masyarakat suku Bugis tidak jauh berbeda dengan pernikahan yang dijalankan atau dikerjakan oleh suku-suku lain. Namun, masyarakat Bugis mempunyai tata cara yang berbeda. Proses perkawinan masyarakat suku bugis adalah sebagai berikut:

\section{Mappese-pese atau Mabbaja Laleng}

Mappese-pese atau Mabbaja Laleng yaitu langkah pertama yang dijalankan pihak laki-laki yaitu mengadakan penjajakan atau suatu cara untuk mengetahui apakah gadis yang akan dipinang tersebut telah memiliki tunangan atau belum. Selain itu, tradisi ini pula dilakukan untuk mengetahui diterima atau tidaknya pinangan nanti.22 Dalam tradisi ini dimulai dengan cara laki-laki yang ingin menikah atau utusannya menanyakan kepada keluarga perempuan apakah perempuan yang ingin dinikahinya tersebut telah memiliki calon atau belum, biasanya masyarakat Bugis memakai bahasa kiasan yang indah untuk menyatakan itu, bahasa

21 George Ritzer, Teori Sosiologi Modern Edisi Ketujuh, (Jakarta: Prenademedia Group, 2014), 275.

22 Nonci, Upacara Adat Istiadat Masyarakat Bugis, (Makassar: CV. Aksara, 2002), 8-9. 
kiasannya sebagai berikut: Tabe' Maraja, engkani ga punnai dare' ta' ? akku de'pi melo' ka' uaseng jamai dare' e, utanengi tanangeng makkigunae.23

Dalam bahasa Indonesia arti bahasa itu adalah mohon maaf yang sebesar-besarnya, apakah kebun itu sudah memiliki tuan, apabila belum mempunyai tuan saya berniat untuk mengolah kebun itu dan menanam tanaman yang sangat berguna. Dalam tradisi inilah masyarakat suku Bugis yang ingin menikah mengetahui calon yang ingin menikah dapat menjatuhkan pilihannya kepada seorang perempuan.

2. Madduta

Pada pase madduta ini merupakan lanjutan dari pase sebelumnya, yaitu dengan cara mengiriman utusan untuk mengajukan lamaran dari seorang laki-laki terhadap perempuan yang sudah disepakati oleh pihak keluarga lakilaki. Utusan itu sepatutnya orang yang dituakan dan tahu prosesi madduta. dia seharusnya piawai memposisikan dirinya supaya keluarga perempuan tidak merasa tersinggung. 24

Dalam tradisi madduta sama dengan khitbah dalam Islam, mengapa digunakan kata madduta sebab madduta dalam bahasa Indonesia dapat diartikan pengiriman perwakilan dari pihak laki-laki kepada pihak perempuan dengan maksud menyampaikan hajatnya atau curahan hatinya. Selain itu, dalam prosesi ini pula akan dibahas mengenai pernikahan, mahar, Sompa, dan uang panai.25

3. Mappettu Ada

Mappetu Ada merupakan memastikan dan mengesahkan semua hasil diskusi yang sudah didiskusikan ketika Madduta atau dalam literasi Bugis disebut "Mappasiarekkeng" seperti jumlah maharnya, berapa besaran

23 Abd. Hayyi, Tokoh Adat Kelurahan Toronipa, Sulawesi Tenggara, Wawancara, 2 Desember 2020.

24 Ibid.

25 Hasta, Tokoh Masyarakat Kelurahan Toronipa, Sulawesi Tenggara, Wawancara 2 Desember 2020. 
uang panai'nya, kapan penyerahan uang panai'nya dan penentuan pelaksanaan resepsi pernikahannya.26

Dalam acara Mappetu Ada, dibicarakan berbagai hal yang berhubungan dengan pernikahan yang meliputi :

a. Tandra Esso (Penentuan Hari)

Penentuan pesta pernikahan dilakukan dengan menentukan beberapa elemen, seperti waktu luang keluarga. Menurut Tokoh Agama Kelurahan Toronipa, Tanta Esso atau Mattiri Esso ialah menetapkan jadwal pelaksanaan yang biasanya meminta pendapat kepada orang tua yang ada di Toronipa, dengan melihat bulan dan penetapan sesuai dengan kalender hijriah. Penetapan hari pesta di Kelurahan Toronipa dilakukan dengan melihat bulan dengan menggunkan Ilmu Falakiah yang di ajarkan secara turun temurun.27

b. Doi Menre (Uang Belanja)

Sesudah menentukan hari pernikahan, maka hal yang penting dilakukan selanjutnya adalah menentukan jumlah uang belanja yang akan diserahkan oleh mempelai laki-laki kepada mempelai perempuan, atau yang sering di bahasakan oleh masyarakat Toronipa dengan sebutan Doi Cappue Iandre Api (uang yang habis di lahap api) maksudnya uang yang digunakan pada saat resepsi pernikahan.28

Besaran uang belanja ditentukan menurut kelaziman atau kesepakatan antar anggota keluarga terlebih dahulu yang akan mengadakan pesta perkawinan. Selain uang belanja, terdapat juga seserahan yang dinamakan Leko. Leko tersebut diberikan bersamaan dengan diantarnya pengantin laki-laki ke rumah pengantin perempuan untuk melangsungkan akad nikah. Leko tersebut biasanya terdiri dari kelengkapan perempuan mulai dari ujung rambut

26 Abd. Hayyi, Tokoh Adat Kelurahan Toronipa, Sulawesi Tenggara, Wawancara, 2 Desember 2020.

27 Rustan, Tokoh Agama Kelurahan Toronipa, Sulawesi Tenggara, Wawancara, 2 Desember 2020.

28 Abd. Hayyi, Tokoh Adat Kelurahan Toronipa, Sulawesi Tenggara, Wawancara, 2 Desember 2020. 
sampai ujung kaki yang terdiri dari, make up, handuk, sepatu, buah-buahan dan lain sebagainya.

c. Sompa

Sompa atau mahar merupakan pemberian wajib lakilaki kepada perempuan yang dinikahinya. Seperti benda berharga atau uang, sebagai syarat sah dari perkawinan. Jumlah Sompa disebutkan mempelai laki-laki pada saat perkawinan (akad) yang ketentuan jumlahnya berbedabeda sesuai stratifikasi sosial seseorang.29

Menurut Tokoh Adat Kelurahan Toronipa, Sompa adalah Pabbere yang diserahkan pada saat pernikahan seperti uang, emas, atau tanah.30 Sompa yang diberikan pada saat dulu dan sekarang di daerah Bugis, dinilai dengan mata uang lama atau masyarakat Bugis menyebutnya Rella.

Bagi golongan ningrat atas sompanya disebut dengan kati' atau sejumlah 88 Real ditambah Satu orang hamba senilai 40 real dan satu ekor kerbau senilai 25 Real. Sompa bagi perempuan kalangan bangsawan tinggi dinamakan Sompa Bocco (Sumpah Puncak) yang mencapai 14 kati. Sedangkan bagi perempuan kalangan bangsawan menengah kebawah hanya satu kati, bagi orang baik-baik (To Deceng) setengah kati, bagi kalangan orang biasa seperempat kati.31

Selain tradisi di atas terdapat pula tradisi yang tidak masuk dalam rangkaian dalam tradisi di atas, tradisi tersebut adalah:

\section{Mappacci}

Mappacci merupakan tradisi perkawinan yang masih diterapkan hingga saat ini atau turun temurun. Ada

\footnotetext{
29 Riady Lamallongeng Asmat, Dinamika Perkawinan Adat dalam Masyarakat Bugis Bone, (Makassar: Dinas Kebudayaan dan Pariwisata Kab. Bone, 2007), 17.

30 Abd. Hayyi, Tokoh Adat Kelurahan Toronipa, Sulawesi Tenggara, Wawancara, 2 Desember 2020.

31 Riady Lamallongeng Asmat, Dinamika Perkawinan Adat, 18.
} 
beberapa unsur yang harus disiapkan dalam tradisi ini adalah: lilin yang terus menyala, beras yang telah digoreng, bantal, tujuh lembar sarung, daun pisang, daun nangka, gula aren, kelapa, dan daun pacci (daun inai).32 Rangkaian prosesi ini dilakukan oleh masing-masing pasangan sehari sebelum terselenggaranya prosesi akad nikah.

Tradisi mappacci oleh masyarakat Bugis dimaknai sebagai proses untuk membersihkan pasangan yang akan menikah. membersihkan yang dimaksud adalah membersihkan dari segala hal-hal yang tidak baik sebelum melangsungkan perkawinan.33 Selain itu pula, dalam tradisi mappacci terdapat pembacaan Barazanji yang menyimbolkan kecintaan kepada Nabi Muhammad SAW.34

Jalannya prosesi mappacci adalah sebagai berikut:35

a. Calon pengantin duduk di laming atau tempat yang telah disediakan.

b. Kelompok pembaca barazanji telah duduk di tempat yang telah disediakan

c. Sampai pembaca barazanji membacakan "Asrakal Badrun Alaina" semua pembaca barazanji berdiri maka dimulailah prosesi perosesi tersebut, sementara bacaan barazanji masih tetap dibacakan.

Pada tradisi ini tetap menanamkan nilai-nilai keislaman di dalmnya, karena dalam prosesi tersebut dimulai dengan membaca ayat suci al-Qur'an dan barazanji sebagai pertanda kesyukuran kepada Allah SWT dan puja pujian kepada Nabi Muhammad atas nikmat yang dirasakan saat itu.36

32 Saprinah et al, "Nilai-nilai Yang Terkandung dalam Budaya Mappacci, " Jurnal Selami Ips, 212.

33 Rustan, Tokoh Agama Kelurahan Toronipa, Sulawesi Tenggara, Wawancara, 2 Desember 2020.

34 Ibid.

35 Ibid.

36 Adella Nur Shafira, "Kajian Makna dan Pesan dalam Tradisi Mappacci Pada Pernikahan Masyarakat Suku Bugis di Kabupaten Sinjai", (Skripsi--Program Studi Pendidikan Bahasa dan Sastra Indonesia, Fakultas Keguruan dan Ilmu Pendidikan, Universitas Muhammadiah Makassar, 2018), 20. 


\section{Pemberian Leko'}

Pemberian Leko' atau seserahan dalam masyarakat Bugis merupakan sesuatu yang mesti ada dalam tradisi pernikahan suku Bugis, bahkan hal ini dianggap wajib untuk diberikan. Dalam pemberian leko', masyarakat bugis memberikan semua kebutuhan wanita dari ujung rambut sampai ujung kaki, seperti mukena, baju, pakaian dalam, lipstik, bedak, cermin, sisir, sendal dan lain-lain. Selain itu, adapula pemberian leko' dalam bentuk buah-buahan yang disimpan di dalam wadah (walasuji) yang berisi, nangka, pisang, tebuh, nenas, kelapa, salak dan buah lontar.37 Sedangkan wadah untuk menyimpan benda-benda tersebut adalah walasuji yang terbuat dari ayaman bambu yang berbentuk segi empat.

\section{Islam dan Adat dalam Tradisi Perkawinan Masyarakat Suku Bugis: Analisis Interaksionisme Simbolik}

Sejak awal perkembangan Islam di dataran Arab, masyarakat Arab pada saat itu telah memiliki tradisi dan adat istiadat yang memiliki kekuatan hukum dalam masyarakat, maka tak ayal jika Nabi Muhammad serta para sahabatnya banyak memperaktikkan tradisi budaya tersebut yang kemudian dijadikan sebagai hukum bagi umat Islam.38 Di Indonesia, masuknya Islam mampu membawa pengaruh besar dalam dimensi budaya masyarakat adat.39

Masyarakat suku Bugis dalam menjalankan tradisi perkawinan menempatkan nilai-nilai budaya di dalamnya yang dijabarkan dalam sebuah interaksi yang memiliki simbol-simbol atau makna tersendiri. Dalam teori Interaksionisme simbolik disebutkan bahwa individu menanggapi suatu simbol dalam lingkungan mereka. Demikian halnya masyarakat suku Bugis

37 Abd. Hayyi, Tokoh Adat Kelurahan Toronipa, Sulawesi Tenggara, Wawancara, 2 Desember 2020.

38 Ratno Lukito, Pergumulan Antara Hukum Islam dan Adat di Indonesia, (Jakarta: Perpustakaan Nasional, 1998), 6-10.

39 Abdul Hadi WM, "Terjadinya Kekosongan Kultural di Tubuh Umat Islam", Suara Muhammadiyah, 2006, 19. 
menempatkan simbol-simbol adat sebagai instrument budaya yang memiliki makna tersirat di dalam tradisinya.

Pada tradisi perkawinan suku Bugis terdapat beberapa instrument-instrumen adat memiliki nilai yang mengandung makna. Adapun tradisi-tradisi yang memiliki nilai interaksionisme simbolik adalah sebagai berikut :

1. Tradisi mappese-pese atau mabbaja laleng. Dalam tradisi ini, masyarakat Bugis meyakini, bahwa dengan melakukan tradisi ini mereka dapat mengetahui, bahwa perempuan tersebut telah memiliki pasangan atau belum, sehingga apabila mereka mengetahui bahwa perempuan tersebut telah memiliki tunangan, mereka akan mengurungkan niatnya untuk menikahi perempuan itu.40 Hal tersebut dilandaskan pada hadist Nabi Muhammad SAW yang dipegang teguh. Hadis tersebut adalah tentang haramnya melamar wanita yang telah dilamar oleh orang lain. Adapun arti hadis tersebut adalah sebagai berikut:41

Nabi Muhammmad SAW melarang sebagian dari kalian untuk berjual beli atas jual beli sebagian yang lain. Dan janganlah seseorang melamar (seorang wanita) atas lamaran saudaranya hingga pelamar pertama meninggalkannya atau member izin kepadanya.

Sebagai masyarakat yang memegang teguh ajaran agama Islam, masyarakat suku Bugis mematuhi aturan hukum di atas. Selain itu, konsensus adat juga memberikan legitimasi kepada masyarakat untuk tidak lagi melanjutkan ke prosesi selanjutnya dengan alasan, bahwa dengan melamar di atas lamaran orang lain akan menyebabkan seseorang itu melanggar adat yang telah ditentukan.

Prosesi adat ini, sesuai dengan konsep yang dikemukakan oleh Mead dalam teorinya, yaitu konsep Mind atau pikiran dalam interaksionisme simbolik. Dalam konsep

40 Rustan, Tokoh Agama Kelurahan Toronipa, Sulawesi Tenggara, Wawancara, 2 Desember 2020.

41 HR. Bukhari: 4746- Tentang Hukum Melamar Wanita Yang Sudah Dilamar, https://risalahmuslim.id/hukum-melamar-wanita-yang-sudah-dilamar/, diakses 10 Desember 2020. 
tersebut disebutkan bahwa pikiran muncul dan berkembang dari proses sosial. pikiran dalam diri memungkinkan seseorang untuk menyelesaikan masalah atau perkara yang muncul ditengah-tengah proses sosial. demikian halnya masyakat suku Bugis yang dapat menyelesaikan proses sosial yang terjadi di tengah-tengah mereka, jika dikaitkan dengan prosesi mappese-pese atau mabbaja laleng tersebut maka, akan melahirkan dua kemungkinan apakah prosesi akan dilanjutkan ke tahap selanjutnya atau tidak. Prosesi dapat dilanjutkan jika tidak ada persoalan atau masalah yang timbul dengan tetap berpegang teguh pada norma adat dan agama, begitupun sebaliknya.

2. Tradisi madduta atau pengiriman utusan ke rumah perempuan pasti melibatkan orang yang cakap dalam berbicara atau orang yang dituakan. Prosesi ini dilakukan agar keluarga perempuan tidak merasa terjamah oleh perkataan atau perbuatan selama prosesi itu berlangsung, sebab dalam prosesi ini dibicarakan mengenai pernikahan, mahar, sompa dan doi' mendre'. Menurut tokoh masyarakat Kelurahan Toronipa, seperti ini dilakukan sebagai bentuk penghargaan atau bentuk kasih sayang antar sesama manusia,42 Sebab masyakat suku Bugis memegang teguh budaya Siri' yaitu budaya malu yang menekankan untuk menjaga harga diri sendiri dan harga diri orang lain. 43

Salah satu bentuk kepatuhan masyarakat suku Bugis dalam Agama Islam dengan menerapkan segala sesuatu sesuai dengan ketentuan Islam, demikian halnya dengan prosesi di atas dimaknai sebagai bentuk penghargaan kepada orang lain. Hal tersebut tertuang dalam al-Qur'an Surah AlHujurat ayat 10 yang artinya sebagai berikut. 44

Orang-orang beriman itu Sesungguhnya bersaudara. Sebab itu damaikanlah (perbaikilah hubungan) antara kedua

42 Hasta, Tokoh Masyarakat Kelurahan Toronipa, Sulawesi Tenggara, Wawancara, 2 Desember 2020.

43 Ibid.

44 Q.S. Al Hujurat (49): 10 
saudaramu itu dan takutlah terhadap Allah, supaya kamu mendapat rahmat.

Jika dikaitkan dalam konsep self atau diri dalam teori Mead, dapat di katakan bahwa tradisi di atas sejalan dengan konsep self (diri). Dalam konsep self karakter pribadi dapat dipengaruhi oleh nilai dan norma budaya yang berkembang di tengah-tengah masyarakat Bugis yang mengedepankan rasa siri' dalam kehidupannya sehingga masyarakat Bugis memiliki sikap dalam bertindak.

3. Tradisi mappetuada atau meresmikan semua hasil pembicaraan yang telah dibahas pada prosesi sebelumnya. Dalam prosesi ini pula dilakukan tandra esso atau penentuan hari, hal itu dilakukan dengan menggunakan Ilmu Falakiah yang diajarkan turun temurun. Dalam tradisi ini pula, masyarakat suku Bugis Kelurahan Toronipa, menggunakan Ilmu yang bersumber dari ilmuan-ilmuan Islam. Hal ini menandakan bahwa masyarakat Bugis tetap menggunakan ajaran Islam dalam setiap tradisi-tradisinya.

Dalam tradisi mappetuada terdapat pembicaraan mengenai penentuan jumlah uang panai' (uang belanja) yang besarannya ditentukan oleh kelaziman atau kesepakatan dari kedua belah pihak. Biasanya penentuan jumlah itu dilihat dari pendidikan, strata sosial dan pekerjaan. Selain itu, adapula tradisi pembicaraan sompa atau mahar untuk perempuan yang akan dinikahi. Pemberian uang panai dan sompa tersebut merupakan spirit keislaman yang dijalankan oleh masyarakat Bugis, yaitu dengan meninggikan derajat seorang wanita melalui pemberian mahar sesuai dengan tingkatan strata sosialnya. Selain itu, pernikahan masyarakat bugis dengan memberikan mahar berupa benda berharga lainnya, seperti emas, sebidang tanah beserta isinya, dan lain-lain, ini didasarkan pada penghayatan atas al-Qur'an surah AnNisa/4:4 yang artinya: Berikanlah maskawin (mahar) kepada wanita (yang kamu nikahi) sebagai pemberian dengan penuh kerelaan. kemudian jika mereka menyerahkan kepada kamu sebagian dari maskawin itu dengan senang hati, Maka makanlah (ambillah) pemberian itu (sebagai makanan) yang 
sedap lagi baik akibatnya. Sehingga tradisi mappettuada yang dilaksanakan tersebut sesuai dengan konsep society atau masyarakat dalam teori interaksioisme simbolik yang diperkenalkan oleh George Herbert Mead. Mead melihat proses sosial yang dijalankan oleh masyarakat mempunyai peranan penting dalam membentuk pikiran dan diri sehingga tradisi yang dijalankan tetap dilestarikan karena sejalan dengan norma agama dan adat.

4. Tradisi mappacci oleh masyarakat Bugis di Kelurahan Toronipa memaknai sebagai proses untuk membersihkan pasangan yang akan menikah. Membersihkan yang dimaksud adalah membersihkan dari segala hal-hal yang tidak baik sebelum melangsungkan perkawinan.45 Selain itu, dalam tradisi mappacci ada proses pembacaan Barazanji. Hal tersebut mengindikasikan, bahwa Masyarakat Bugis di Kelurahan Toronipa melakukan hal tersebut selain untuk menanamkan nilai-nilai Islam dalam tradisinya juga dimaksudkan untuk menanamkan rasa kecintaan terhadap Nabi Muhammad SAW.

Dalam tradisi mappacci terdapat pula beberapa benda yang digunakan, benda tersebut memiliki makna dan pesan yang berbeda-beda pula adapun penjabarannya dijelaskan dalam tabel berikut ini :

Tabel makna dan pesan prosesi mappacci.46

\begin{tabular}{lll}
\hline Objek benda & Makna & Pasan \\
\hline Bantal & $\begin{array}{l}\text { Saling } \\
\text { menghormati }\end{array}$ & $\begin{array}{l}\text { Diharapkan agar } \\
\text { pengantin senantiasa } \\
\text { menjaga martabat dan } \\
\text { saling menghormati }\end{array}$ \\
\hline Sarung Sutera & $\begin{array}{l}\text { Sikap istiqamah } \\
\text { dan ketekunan }\end{array}$ & $\begin{array}{l}\text { Diharapkan agar calon } \\
\text { mempelai dapat } \\
\text { memetik ibrah dari } \\
\text { pengerajin sutera dalam }\end{array}$ \\
\hline
\end{tabular}

45 Rustan, Tokoh Agama Kelurahan Toronipa, Sulawesi Tenggara, Wawancara, 2 Desember 2020.

46 Adella Nur Shafira, Kajian Makna dan Pesan , 46. 


\begin{tabular}{|c|c|c|}
\hline & & $\begin{array}{lr}\text { hal ketekunan } & \text { untuk } \\
\text { menafkahi } & \text { dan } \\
\text { mengurus } & \text { rumah } \\
\text { tangga } & \end{array}$ \\
\hline $\begin{array}{l}\text { Daun Pucuk } \\
\text { Pisang }\end{array}$ & $\begin{array}{l}\text { Kehidupan yang } \\
\text { saling } \\
\text { berkesinambung } \\
\text { an sebagaimana } \\
\text { daun pisang } \\
\text { yang belum } \\
\text { kering akan } \\
\text { muncul daun } \\
\text { mudanya untuk } \\
\text { meneruskan } \\
\text { kehidupan }\end{array}$ & $\begin{array}{l}\text { Diharapkan agar calon } \\
\text { mempelai tidak pernah } \\
\text { berhenti berupaya dan } \\
\text { berusaha untuk } \\
\text { mempertahankan } \\
\text { hubungan pernikahan }\end{array}$ \\
\hline $\begin{array}{l}\text { Daun } \\
(\text { Pacci })\end{array}$ & $\begin{array}{l}\text { Kesucian atau } \\
\text { kebersihan }\end{array}$ & $\begin{array}{l}\text { Diharapkan agar calon } \\
\text { mempelai bersih dan } \\
\text { suci dalam menjalankan } \\
\text { bahtra rumah tangga }\end{array}$ \\
\hline Daun Nangka & Kejujuran & $\begin{array}{l}\text { Diharapkan agar calon } \\
\text { mempelai dalam } \\
\text { kehidupan yang dilalui } \\
\text { dalam pasangan suami } \\
\text { istri dalam keadaan } \\
\text { tentram dan bahagia } \\
\text { yang dilandasi oleh } \\
\text { kejujuran }\end{array}$ \\
\hline Beras Melati & $\begin{array}{l}\text { Berkembang } \\
\text { dengan baik }\end{array}$ & $\begin{array}{l}\text { Diharapkan agar calon } \\
\text { pengantin dapat } \\
\text { berkembang dan } \\
\text { berdikari didalam } \\
\text { keluarga yang dilandasi } \\
\text { dengan cinta, kasih dan } \\
\text { kesejahtraan }\end{array}$ \\
\hline
\end{tabular}




\begin{tabular}{|c|c|c|}
\hline Lilin & $\begin{array}{l}\text { Memberikan } \\
\text { sinar pada jalan } \\
\text { yang ditempuh }\end{array}$ & $\begin{array}{l}\text { Diharapkan agar calon } \\
\text { mempelai mendapat } \\
\text { petunjuk dari Allah SWT } \\
\text { dalam kehidupan } \\
\text { rumah tangganya }\end{array}$ \\
\hline Wadah Pacci & $\begin{array}{l}\text { Pasangan yang } \\
\text { saling mengisi } \\
\text { satu sama lain }\end{array}$ & $\begin{array}{lr}\text { Diharapkan } & \text { agar } \\
\text { mempelon } \\
\text { bersama } & \text { tetap } \\
\text { menjalin } & \text { dalam } \\
\text { rumah tangga } & \end{array}$ \\
\hline $\begin{array}{l}\text { Gula Aren } \\
\text { dan Kelapa }\end{array}$ & $\begin{array}{l}\text { Melambangkan } \\
\text { rasa nikmat }\end{array}$ & $\begin{array}{l}\text { Diharapkan agar calon } \\
\text { mempelai mendapatkan } \\
\text { rasa nikmat dengan } \\
\text { saling melengkapi satu } \\
\text { sama lain seperti manis } \\
\text { dan pahitnya kehidupan }\end{array}$ \\
\hline
\end{tabular}

Sebagai masyarakat yang mayoritas Muslim, masyarakat suku Bugis meskipun menggunakan beberapa instrumen adat yang memiliki makna tertentu bagi mereka tidak mengenyampingkan ajaran agama Islam dalam teradisi tersebut misalnya saja pembacaan al-Qur'an dan pujian kepada Nabi Muhammad dalam bentuk pembacaan barazanji.

5. Tradisi pemberian leko'. Pemberian Leko' atau seserahan dalam masyarakat Bugis merupakan sesuatu yang mesti ada dalam tradisi pernikahan suku Bugis, bahkan hal ini dianggap wajib untuk diberikan. Dalam pemberian leko' masyarakat bugis memberikan semua kebutuhan wanita dari ujung rambut sampai ujung kaki, seperti mukena, baju, pakaian dalam, lipstik, bedak, cermin, sisir, sendal dan lain-lain yang memberikan makna tanggung jawab seorang suami untuk menghargai dan menafkahi istrinya.47

Selain itu adapula pemberian leko' dalam bentuk buahbuahan yang disimpan di dalam wadah (walasuji) yang berisi,

47 Abd. Hayyi, Tokoh Adat Kelurahan Toronipa, Sulawesi Tenggara, Wawancara, 2 Desember 2020. 
nangka, pisang, tebuh, nenas, kelapa, salak dan buah lontar yang masing-masing memiliki makna yang esensinya menuju kepada keharmonisan dalam berumah tangga nantinya. 48

Adapun makna dari walasuji bagi masyarakat Bugis adalah walasuji menggunakan bahan dasar bambu karena bambu memiliki makna filosofi tinggi. Pohon bambu memiliki struktur akar yang sangat kuat hal itu melambangkan bahwa masyarakat suku Bugis memiliki pemahaman, penghayatan dan pengamalan yang sangat kuat bagi masyarakat suku Bugis dalam hal keimanan kepada Allah SWT. Selain itu bentuknya yang segi empat menandakan empat arah mata angin yakni timur, barat, selatan dan utara yang memiliki makna kesempurnaan yaitu keberanian, kebangsawanan, kekayaan dan ketampanan atau kecantikan.49

Dengan demikian dalam teori yang dijelaskan oleh Mead tentang Mind, Self dan Society atau tiga konsep dasar sehingga interaksi dalam masyarakat memiliki makna atau simbol tertentu. Begitu halnya dalam tradisi perkawinan suku Bugis di Kelurahan Toronipa yang pola interaksinya memiliki simbol-simbol atau pemaknaan yang sejalan dengan doktin agama Islam. Hal tersebut memberikan legitimasi bahwa Islam dan adat dalam tradisi perkawinan suku Bugis berjalan beriringan atau bentuk penerimaan masyarakat Bugis dengan nilai-nilai Islam dijabarkan dalam tradisitradisi yang dijalankan.

\section{Penutup}

Berdasarkan pembahasan di atas, dapat ditarik kesimpulan bahwa masyarakat suku Bugis di Kelurahan Toronipa dalam tradisi perkawinannya menempatkan simbolsimbol adat sebagai instrumen budaya yang memiliki nuansa nilai-nilai Islam dalam tradisinya.

Tradisi-tradisi yang dijalankan masyarakat Bugis dalam bidang pernikahan didasari oleh konsep adat yang masih

48 Ibid.

49 Makna Dibalik Sulapa' Eppa' Lala Suji Bugis Makassar, http://kabarmakassar.com/posts/view/1611/makna-dibalik-sulapa-eppalawa-suji-bugis-makassar.html, diakses 1 Maret 2021. 
dipegang teguh, yaitu konsep siri' dan mengedepankan nilainilai agama dan tradisi lokal yang masih dijalankan hingga saat ini. Hal tersebut memberikan legitimasi bahwa Islam dan adat dalam tradisi perkawinan suku Bugis berjalan beriringan.

\section{Daftar Pustaka}

Ardianto, Elvinaro, Komala, Lukianti dan Karlinah, Siti.

Komunikasi Massa Suatu Pengantar. Revisi Bandung: Simbiosa Rekatama Media, 2007.

Asmat, Riady Lamallongeng. Dinamika Perkawinan Adat dalam Masyarakat Bugis Bone. Makassar : Dinas Kebudayaan dan Pariwisata Kab. Bone, 2007.

Berger, Artur Asa. Tanda-Tanda dalam Kebudayaan Kontemporer. terj. M. Dwi Mariyanto dan Sumarto. Yogyakarta: Tiara Wacana, 2004.

Hadi WM, Abdul. "Terjadinya Kekosongan Kultural di Tubuh Umat Islam". Suara Muhammadiyah, 2006.

Haryanto, Sindung. Spektrum Teori Sosial dari Klasik Hingga Postmodern. Yogyakarta: AR-RUZZ MEDIA, 2012.

Lukito, Ratno. Pergumulan Antara Hukum Islam dan Adat di Indonesia. Jakarta: Perpustakaan Nasional, 1998.

Mulyana, Dedi. Metodologi Penelitian Kualitatif. Bandung: Rosdakarya, 2002.

Nonci. Upacara Adat Istiadat Masyarakat Bugis. Makassar: CV. Aksara, 2002.

Ritzer, George dan Goodman, Douglas J, Teori Sosiologi Modern, Jakarta: CV Rajawali.

Ritzer, George. Teori Sosiologi Modern Edisi Ketujuh. Jakarta: Prenademedia Group, 2014.

Saprinah dkk, "Nilai-nilai Yang Terkandung Dalam Budaya Mappacci Pada Rangkaian Pelaksanaan Perkawinan Orang Bugis (Studi di Desa Biru Kecamatan Poleang Timur Kabupaten Bombana), "Jurnal Selami Ips, Vol. 3:47 Juni, 2018.

Seliana dkk. "Makna Simbolik Mappasikarawa dalam pernikahan suku Bugis di Sebatik Nunukan," Jurnal Ilmu Budaya, Vol. 2:3 Juni, 2018.

Sobur, Alex. Semiotika Komunikasi. Bandung: Rosda Karya, 2004. 
Soekanto, Soerjono. Hukum Adat Indonesia. Jakarta: CV. Rajawali.

Usriah, "Tradisi Kelakat Dalam Perkawinan Masyarakat Muslim Kelurahan Loloan Timur Kabupaten Jembrana Bali," Jurnal Hukum dan Syariah, Vol. 1:1.

Wekke, Ismail Suardi, "Islam dan Adat Dalam Pernikahan Masyarakat Bugis di Papua Barat," Jurnal Thaqafiyyat, Vol. 13:2 Desember 2012.

Widyawati, "Makna Tradisi Uang Panai Dalam Adat Pernikahan Suku Bugis di Sungai Guntung Kecamatan Kateman Kabupatan Indragiri Hilir Provinsi Riau," Jurnal JOM FISIP, Vol. 5:2 Desember, 2018.

Yansa, Hajra, dkk, "Uang Panai' dan Status Sosial Perempuan dalam Perspektif Budaya Siri' Pada Perkawinan Suku Bugis Makassar Sulawesi Selatan," Jurnal Pena, Vol. 3:2. 534.

HR. Bukhari: 4746- Tentang Hukum Melamar Wanita Yang Sudah Dilamar, https://risalahmuslim.id/hukummelamar-wanita-yang-sudah-dilamar/ akses 10 Desember 2020.

Keharmonisan Relasi Suku Bugis dan Suku Toraja, http://www.ugm.ac.id/id/berita/18152-keharmonisanrelasi-suku-bugis-dan-toraja, diakses Tanggal 28 Februari 2021.

Makna Dibalik Sulapa' Eppa' Lala Suji Bugis Makassar, http://kabarmakassar.com/posts/view/1611/maknadibalik-sulapa-eppa-lawa-suji-bugis-makassar.html, diakses tanggal 1 Maret 2021.

Abd. Hayyi (Tokoh Adat Kelurahan Toronipa, Kecamatan Soropia Kabupaten Konawe). Wawancara, Sulawesi Tenggara, Desember 2, 2020.

Adnan, Moh. Mus'id, "Tradisi Kawin Boyong dalam Perkawinan Adat Masyarakat Gesikan (Studi Kasus di Desa Gesikan Kec. Grabangan, Kab. Tuban), (Skripsi--Universitas Negeri Malang, 2008). 
Hasta (Tokoh Masyarakat Kelurahan Toronipa, Kecamatan Soropia Kabupaten Konawe). Wawancara, Sulawesi Tenggara, 02 Desember 2020.

Halim, Aridiah. "Tradisi Mappacci dalam Proses Pernikahan Masyarakat Bugis Perspektif Al-'Urf (Studi di desa Sengengpalie, Kec Lappariaja, Kab Watampone, Sulawesi Selatan). (Skripsi--Fakultas Syaraiah Universitas Islam Negeri Malang, 2018).

Rustan (Tokoh Agama Kelurahan Toronipa, Kecamatan Soropia Kabupaten Konawe). Wawancara. Sulawesi Tenggara, 02 Desember 2020. 